Russian Academy of Sciences, Far Eastern Branch

Botanical Garden-Institute

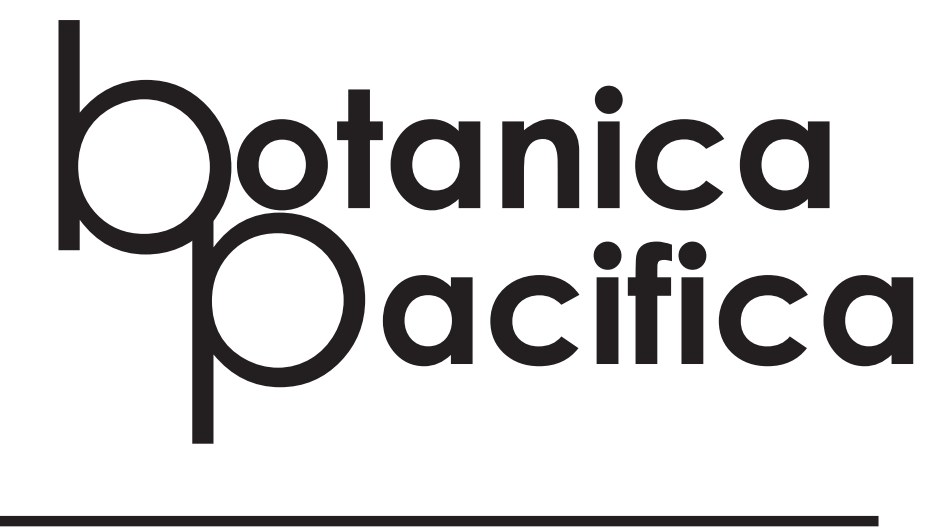

A JOURNAL OF PLANT SCIENCE
AND CONSERVATION

VOLUME 9, NO. 12020 


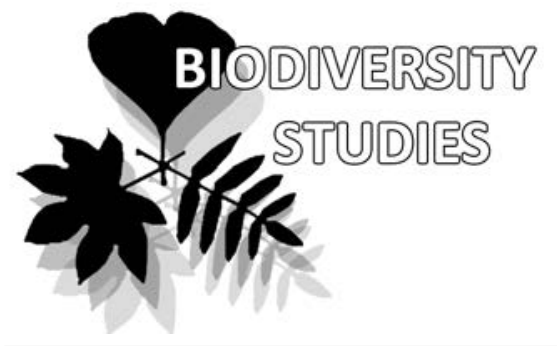

Alexey A. Kechaykin ${ }^{1 *}$

e-mail: alekseikechaikin@mail.ru

Georgy A. Lazkov²

e-mail: glazkov1963@mail.ru

Alexander I. Shmakov ${ }^{1}$

e-mail: alex_shmakov@mail.ru

Sardor A. Usmanov ${ }^{1}$

\begin{abstract}
${ }^{1}$ Altai State University, Barnaul, Russia
${ }^{2}$ Institute for Biology and Soil Science, National Academy of Sciences, Bishkek, Kyrgyzstan
\end{abstract}

* corresponding author

Manuscript received: 09.01.2020

Review completed: 24.04.2020

Accepted for publication: 03.05.2020

Published online: 14.05 .2020

\section{Addition to the flora of Kyrgyzstan}

\author{
Alexey A. Kechaykin'*, Georgy A. Lazkov², Alexander I. Shmakov ${ }^{1} \&$ \\ Sardor A. Usmanov ${ }^{1}$
}

\begin{abstract}
A B S T R A C T
The paper proposes new data and contributions related to distribution of some species from the family Rosaceae in Kyrgyzstan. Five species of the genus Potentilla are newly recorded for the flora of Kyrgyzstan, of which Potentilla tuvinica is a new taxon for the Tian Shan Mountain Range. One species from the genus Fragariastrum and one from the genus Sibbaldia, as well as 16 species of Potentilla have been indicated for some biogeographic regions of Kyrgyzstan for the first time. The area of distribution of Potentilla ferganensis is specified, and data on distribution of Potentilla tobolensis are supplemented. Specific habitats are reported for Potentilla exuta and Potentilla penniphylla described from Kyrgyzstan, but not included in the lists of plants growing in this territory. For each species presented, the general distribution outside Kyrgyzstan is indicated. The endemism of the genus Potentilla in the study area is analyzed. For Potentilla biflora, a nomenclature correction is provided. A map of the biogeographic regions of Kyrgyzstan is presented. It displays the distribution of the rarest Potentilla species.
\end{abstract}

Ke yword s : floristic findings, Pamir-Alai, Tian Shan, Rosaceae, Potentilla, Sibbaldia, Fragariastrum, general distribution, endemism

\section{P E 3 Ю M E}

Кечайкин А.А., Аазьков Г.А., Шмаков А.И., Усманов С.А. Аополнение к фморе Кыргызстана. ПреАставлены новые Аанные о распространении представителей семейства Rosaceae на территории Кыргызстана. Впервые приводятся 5 виАов рода Potentilla, из которых P. twinica является новым таксоном Аля горной системы Тянь-Шаня. По одному виду родов Fragariastrum и Sibbaldia, а также 16 вилов Potentilla впервые указаны Аля отАельных бооогеографических районов. Уточняется район распространения Potentilla ferganensis и лополняется информация о распространении Potentilla tobolensis. Аیя Potentilla exuta и Potentilla penniphylla, описанных с Кыргызстана, но не включенных в списки растений Аанной территории, приводятся конкретные местонахождения на территории респубилики. Распространение наиболее редких видов указано на схематической карте биогеографического районирования. Аیя кажАого вила Аано общее распространение. Аیя Potentilla biflora Аается коррекция автора этого таксона. ПровоАится анализ эндемизма рода Potentilla фцоры исследуемой территории.

КАючевые слова: флористические находки, Памиро-Алай, Тянь-Шань, Rosaceae, Potentilla, Sibbaldia, Fragariastrum, общее распространение, эндемизм
This study is devoted to new findings from the family Rosaceae Juss., namely, the genus Potentilla L. and close taxa of the flora of Kyrgyzstan. The country is located in Central Asia (the term Middle Asia is used in most Russian-language sources). The main part of Kyrgyzstan is occupied by the Tian Shan and Pamir-Alai mountain ranges, intermountain hollows and depressions. In the north-eastern part, there is Issyk-Kul, one of the largest mountain lakes of Eurasia. The highest mountain ranges that cover more than $75 \%$ of the area and large water reservoirs make the climate of Kyrgyzstan unique, which causes its floral diversity. According to the estimates by Lazkov \& Sultanova (2014), the flora of Kyrgyzstan includes 3927 species of wild and adventive vascular plants from 834 genera that belong to 114 families. However, Kamelin (2002) stated more than 4000 species of vascular plants from 870-875 genera and 140 families growing in Kyrgyzstan. For comparison, the floristic diversity of Mongolia with the area almost eight times greater than that of Kyrgyzstan and not less unique nature includes 3127 vascular plants from 683 genera and 112 families (Urgamal et al. 2014).
One of the most numerous families in Kyrgyzstan's flora is the family Rosaceae, where the genus Potentilla is the first in the number of species. The abundance and, hence, diversity of the species composition of the genus Potentilla in floras of the Central Asian republics of the former USSR differ significantly. Thus, only 8 species of Potentilla are cited for Turkmenistan's flora (Blinovsky 1950); for Uzbekistan's flora - 28 species (Botchantsev 1955); for Kyrgyzstan's flora - 29 species (Kashchenko 1957); for Tajikistan's flora - 34 species (Ovczinnikov \& Koczkareva 1975); for Kazakhstan's flora - 48 species (Baytenov 1961). Uneven distribution of species abundance is primarily due to the confinement of these regions (or their proximity) to mountain ranges, which genesis has no common features. For example, the species diversity of Potentilla (and many genera from other families) in Kazakhstan is affected by four different mountain ranges: the Urals (the southern part), the Tian Shan, the Djungar Alatau and the Altai.

The above data on the number of Potentilla species in the Central Asian regions of the former USSR obtained in 
the middle of the last century have changed so far. In particular, according to Lazkov \& Sultanova (2014), the species composition of the genus Potentilla s.l. (including Argentina Hill, Drymocallis Fourr. ex Rydb. and Schistophyllidium (Juz. ex Fed.) Ikonn.) in Kyrgyzstan is represented by 40 species. For more than 55 years, the flora of Kyrgyzstan has been replenished with 11 new Potentilla taxa. Within five years after the release of the second volume of the Cadastre of Flora of Kyrgyzstan (Lazkov \& Sultanova 2014), new data have been gained, which expand understanding of the flora in the study area and distribution of individual Potentilla species.

\section{MATERIAL AND METHODS}

The study was performed on the specimens from the genus Potentilla L. and close taxa of the Kyrgyzstan's flora investigated in several of the largest herbaria, and on the materials collected during fieldworks. Herbarium specimens were investigated in Russian herbaria: LE (St. Petersburg), MW (Moscow), TK (Tomsk), and in collections from other countries: DR (Germany, Dresden), PR (Czech Republic, Prague) and TASH (Uzbekistan, Tashkent). In addition, some of the materials used were taken from electronic herbaria $\mathrm{K}$ (Royal Botanic Gardens Kew 2019), MW (Seregin 2019) and E (Royal Botanic Garden Edinburgh 2019). Fieldworks were carried out in the Prifergansky biogeographic region in 2018. The materials collected during these works are stored in the Herbarium ALTB collections (Russia, Barnaul). Modern revisions of the flora of the Central Asia were used to identify species of the genus Potentilla and related taxa (Li et al. 2003, Soják 2004, 2012, Shah 2009). A map of the biogeographic regions of Kyrgyzstan proposed by Abdrashitova et al. (1996) in the Cadastre of the genetic fund of Kyrgyzstan and Lazkov \& Sultanova (2011) in the Cadastre of Flora of Kyrgyzstan (Fig. 1) was used in the study:

NK - Northern Kyrgyzstan (Chui valley, the Chon-Kemin river valley with adjacent northern slopes of the Kyrgyz range and Kungei Ala-Too);
PI - Issyk-Kul valley (including northern slopes of the Terskei Ala-Too, southern slopes of the Kungei Ala-Too and the Tup river valley);

CT - Central Tian Shan (Sary-Djaz river basin);

WT - Western Tian Shan (including the Toktogul depression, and Talas and Chatkal valleys);

SF - Subfergansky regions of Kyrgyzstan (including southern slopes of the Chatkal and Fergana ranges and northern slopes of the Alai and Turkestan ranges);

IT - Inner Tian Shan (in the north, the region is bounded by the Kyrgyz range, in the southwest, it is bounded by the Fergana range, and in the southeast, it is bounded by the Kokshaal-Too range);

A - Alai valley (including southern slopes of the Alai and northern slopes of the Zaalai ranges).

The taxon nomenclature is given in accordance with the Potentillinae J. Presl subtribe system proposed by Kechaykin \& Shmakov (2016), and the International Plant Name Index (http://www/ipni/org/). Herbarium acronyms are listed according to Index Herbariorum (Thiers 2017). The relevant species and indication of their distribution in Kyrgyzstan and outside the study area are listed below. We provide all data from the herbarium label that can be used to refer the species to a specific biogeographic region. The biogeographic regions where the species was newly found are marked with "*". For some of the taxa, comments are provided. The distribution of the rarest Potentilla species in Kyrgyzstan is displayed on the map.

\section{RESULTS AND DISCUSSIONS New species in the flora of Kyrgyzstan}

Potentilla flabellata Regel et Schmalh.

A: "Alai range, dry meadow steppe, Kosh-Karchi (Kochkorchu) riv. head. 30.06.1936. No. 147. I. Tyshchenko, M. Rozhkovskaya" (MW0840212); "Alai valley, Dzhaylyau Kosh-Carchi, alpine meadows. 27.06.1931. No. 223. S. Lipschitz" (MW0840211, MW0840216) (Fig. 1).

General distribution: Central Asia.

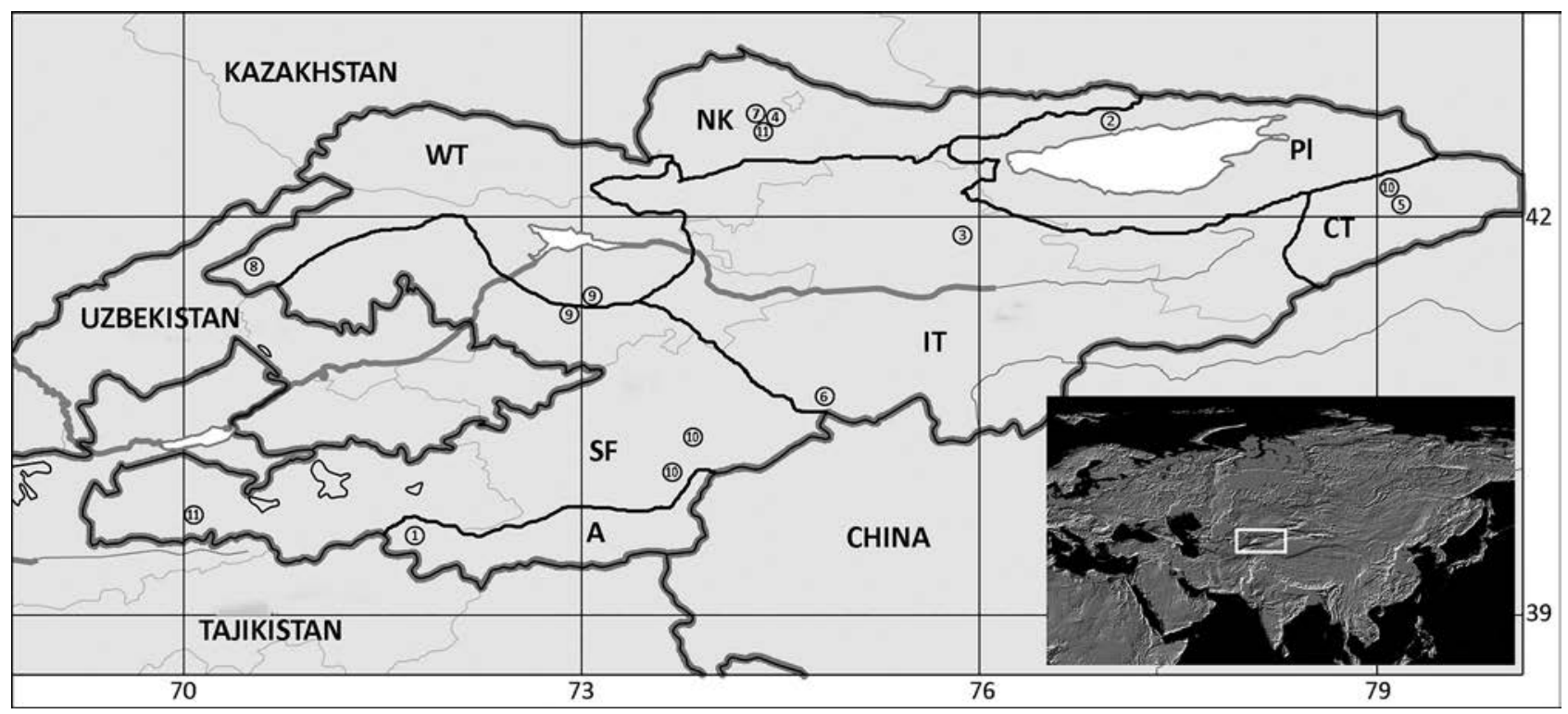

Figure 1 A map of the biogeographic regions of Kyrgyzstan (see explanation in the text) and distribution of the rarest Potentilla L. species (number in circles: $1-P$. flabellata Regel et Schmalh., $2-P$. regelina Th. Wolf, $3-P$. tuvinica Artemov, $4-P$. $\times$ ala-arczae Soják, $5-P$. exuta Soják, 6 - P. ferganensis Soják, 7 - P. × bishkekensis Soják, 8 - P. kamelinii Lazkov, 9 - P. recta L., 10 - P. penniphylla Soják, 11 - P. algida Soják 
The species occurs in four countries: the south-western part of Uzbekistan (Gissar, Zeravshan and Turkestan ranges), Tajikistan (except Khatlon region and northern part of Sogd region), the north-eastern regions of Afghanistan and the north of Pakistan in the Hindu Kush. A new locality discovered in Kyrgyzstan is in the northern boundary of the P. flabellata habitat.

\section{Potentilla recta $\mathrm{L}$.}

SF: "East Fergana, Jalal-Abad distr. Tentyak-su riv. basin, Arslanbob riv. head, walnut forest. 20.06.1927. No. 157, 167. E.P. Korovin" (TASH); "Jalal-Abad region, Fergana range, Bazar-Korgon distr., Kara-Unkur riv. head. $41^{\circ} 22^{\prime} 54^{\prime \prime} \mathrm{N}$, $72^{\circ} 56^{\prime} 04^{\prime E}$. $\mathrm{H}=2200 \mathrm{~m}$ a.s.l. 22.07.2018. S.A. Usmanov" (ALTB) (Fig. 1).

General distribution: North Africa (Algeria); Europe; North (Altai), Southwest, Central and South (northwest) Asia; North America.

Potentilla regelina Th. Wolf

PI: "S slope of Kungei-Alatau range. Bakhtu-Dolonoto riv. basin. 26.06.1936. No. 106. T. Semenikhina" (TASH) (Fig. 1).

Some authors considered $P$. regelina as a synonym for $P$. evestita Th. Wolf (Adylov 1976, Soják 2004, 2009, 2012). The species independence of $P$. regelina is beyond any doubt (Lipsky 1910, Juzepchuk 1941, Baytenov 1961, Kechaykin et al. 2014).

General distribution: North (Altai) and Central Asia.

Potentilla turczaninowiana Stschegl. ( $P$. turczaninowiana Stschegl. subsp. nephogena Soják; P. nephigena Soják, nom. nud. (in sched.)).

WT: "Susamyr range, S and N slopes of Kurumdy pass. 1.08.1925. No. 1231, 1242. M. Sovetkina" (TASH).

SF: "Kirgisia, montes Alai: in pratis subalpinis supra pagum Sachimardan (Chamzaabad) ad merid. versus ab oppido Fergana. $\mathrm{H}=2000 \mathrm{~m}$ a.s.l. 10.07.1979. J. Soják" (K000762410; LE; PR).

CT: "Przhevalsky distr., Myntur pass. 28.07.1912. V. Sapozhnikov, B. Shishkin" (TK); "Central Tian Shan. Syrts, right bank of Sor-Bulak riv. (right-bank tributary of Kuilu riv.). 29.08.1956. I. Shchukin" (MW0840766).

General distribution: North (southern Siberia) and Central Asia.

In one of the studies, J. Soják described P. turczaninowiana Stschegl. subsp. nephogena Soják from his own materials collected in 1981 in Kazakhstan: Zailiyskiy Alatau, Bolshava Almaatinka (Soják 1988). This subspecies is distinguished by petioles and leaflets hairy on the underside (these are usually bare in type subspecies). Earlier, J. Soják collected interesting specimens in Kyrgyzstan, labeled them as $P$. nephigena sp. n. and deposited one of these specimens as an isotype into LE herbarium (cited above). This taxon was not published by J. Soják. Our study of herbarium materials showed that $P$. nephigena and $P$. turczaninowiana subsp. nephogena are identical plants. Later, J. Soják pointed out that the subspecies identified by him has an ambiguous status since its specimens are found throughout the entire habitat of P. turczaninowiana along with type specimens (Soják 2009). Our observations of these plants in nature and the study of herbarium materials revealed transitional forms between $P$. turczaninowiana subsp. nephogena and type subspecies. Thus, we support the opinion of J. Soják and consider that the presence of a small number of hairs on petioles and leaflets of subsp. nephogena can be ecomorphosis. The main morphological differences between $P$. turczaninowiana and closely related taxa are indicated in the studies by J. Soják (1988, 2004, 2007, 2009, 2012).

Potentilla tuvinica Artemov

IT: "N slope of Kara-Jorgo range, Tashkechuu gorge, lowgrass subalpine meadows. 28.06.2010. M.R. Tanybaeva" (LE) (Fig. 1).

General distribution: North and Central Asia (Altai).

This single herbarium specimen is represented by two different species. The upper part of the herbarium specimen dis- plays two specimens of P. tuvinica; the lower part shows one specimen of P. evestita Th. Wolf. The upper specimens are cited by G.A. Lazkov as P. multifida L. X P. sp. Indeed, P. tuvinica is a hybrid species originated through hybridization between $P$. multifida and $P$. evestita, with several closely related taxa (Artemov 2005, Gundegmaa \& Kechaykin 2018). $P$. tuvinica is newly recorded for the Tian Shan mountain range. The nearest locality of this species is approximately $1300 \mathrm{~km}$ to the northeast in the Altai Mts.

\section{New species in some biogeographic regions of Kyrgyzstan}

Fragariastrum biflorum (Willd. ex D.F.K. Schltdl.) Kechaykin et Shmakov

KYRGYZSTAN: NK, PI, SF and IT as Potentilla biflora Willd. ex D.F.K. Schltdl. (Lazkov \& Sultanova 2011); CT* _ "Irtash riv. basin and Jaman-Su riv. valley. 08.1936. No. 419. E. Korovin" (TASH)

General distribution: North and Central Asia; North America.

Schlechtendal is cited as the only author of P. biflora in one of the studies (Braun \& Heuchert 2013) and in the Internarional Plant Name Index and Tropicos (http:/ / www.tropicos.org/) databases. In other studies, Willdenow is referred to as the only author of this species (Soják 2004, 2012). Most likely, a technical error was made in the sources cited above. Not only the name, but also the description of this species was first given by Willdenow. Like many other Willdenow's potentillas, Potentilla biflora was validated by Schlechtendal after the death of Willdenow (Schlechtendal 1816). Thus, according to Art. 46 of the International Code of Nomenclature for Algae, Fungi, and Plants (Turland et al. 2018), this species must be attributed to Willd. ex D. F. K. Schltdl.

\section{Potentilla agrimonioides $\mathrm{M}$. Bieb.}

KYRGYZSTAN: IT as P. stanjukoviczii Ovcz. et koczk. (Lazkov \& Sultanova, 2011); A* - "Osh region, S slopes of Alai range, vill. Daraut-Korgon, $3 \mathrm{~km}$ to the north. Rocks outputs. $\mathrm{H}=3600 \mathrm{~m}$ a.s.l. 25.08.1957. Yu.Ya. Fedorov" (MW0839897), "Vill. Daraut-Korgon env., rocks. H = 3000 m a.s.l. 29.07.1957. Yu.Ya. Fedorov" (MW0839898), "Alai range, alpine meadows in Lenin Peak env. 19-21.07.1975. S. Tumanyan" (MW0894809), "Alay valley, Daraut-Tag mountain. N slope. Rocks and scree slope. 26.06.1936. No. 94. I. Tyshchenko, M. Rozhkovskaya" (TASH); PI* - "Terskey-Alatau, catchment of Chon-Kyzyl-Su riv., Kara-Bashkak riv. valley. $\mathrm{H}=3200 \mathrm{~m}$ a.s.1. 22.06.1949. T. Gordeeva" (MW0839899), "Korumdu-Tal am nordl. Abh. von Terskei-Tau. 1.06.1902. No. 8. V. Saposhnikov" (DR); CT* - "Sary-Djaz riv. basin, lower part of Berkut riv. valley. 07.1961. I. Shchukin" (MW0839901), "Central Tian Shan. Right bank of Inylchek riv., above confluence of AchekTash riv. The second terrace. 27.06.1939. No. 29. V. Yakovleva" (LE), "Sarydschass-Tal neben Mäadung Kuelu. Terrassen. 06.1902. No. 11. V. Saposhnikov" (DR).

General distribution: Eastern Europe (southeast); North (southern Siberia), Southwest, Central, South (northwest) Asia.

This mountain-steppe and rock species that is wide-spread in Eurasia exhibits several variations within its habitat (Soják 1987a), which are geographically undifferentiated. We agree with the opinion of J. Soják that $P$. stanjukoviczii is synonymous with P. agrimonioides (Soják 1987a, Soják 2009).

\section{Potentilla algida Soják}

KYRGYZSTAN: SF; NK* - "Kirgisia, Tian-Schan montes Kirgizskij Chrebet: locis graminosis in valle rivuli Ala-Arca ad meridiem versus ab oppido Frunze, $\mathrm{H}=1500-2000 \mathrm{~m}$ a.s.l. 8.07.1979. J. Soják" (E00663808) (Fig. 1).

General distribution: Central Asia.

Potentilla angustiloba T.T. Yü et C.L. Li.

KYRGYZSTAN: IT* - "Kara-Tash tract, bank of Tulek riv. 8.07.1937. K. Halzova" (TASH); PI* - "Issyk-Kul depression, $15 \mathrm{~km}$ to the southeast of Rybachiy. Desert on the 
southern shore of lake. 1.06.1958. No. 1032. I.A. Gubanov" (MW0839905, MW0839906).

General distribution: North (Altai) and Central Asia.

This species was previously cited for the flora of Kyrgyzstan. CT: "Semirech. region, Przhevalsky distr., Kuelu riv. opposite Torp[u] riv. N steppe slope. 11.08.1912. V. Sapozhnikov, B. Shishkin" (herbarium specimen is defined as P. multifida L. var. angustifolia Lehm. and P. multifida L. var. nubigena Th. Wolf) (TK) (Kechaykin 2016); "Semirech. region, Przhevalsky distr., Ken-Su riv., Aksai western source, h. solon. desert steppe. 7.07.1913 V. Sapozhnikov" (TK) (Kechaykin 2016).

\section{Potentilla approximata Bunge}

KYRGYZSTAN: NK; PI* - "Issyk-Kul depression, Kungei-Alatau range, $75 \mathrm{~km}$ on NNE from Rybachiy. Steppe zone of mountains, Cholpon-Ata gorge. 3.07.1958. I.A Gubanov" (MW0839930), "Issyk-Kul depression, Kara-Bulung peninsula. 07.1975. I. Shchukin" (MW0839894), "Depression of lake Issyk-Kul, south-eastern coast of lake, vill. Pokrovka env., along aryk bank. 15.07.1975. I. Shchukin" (MW0839932), "Issyk-Kul depression, Karakol distr., vill. Sokolovka env. W slope of mountains. 20.08.1932. G. Sumnevich" (the specimen collected from vill. Sokolovka env is defined as P. fedtschenkoana Siegfr. ex Th. Wolf) (TK), "S slope of Kungei-Alatau range, Ak-Shibak tract, foothills, right side of Kara-Su riv. " (TASH).

General distribution: Eastern Europe; North and Central Asia.

\section{Potentilla argentea $\mathrm{L}$.}

KYRGYZSTAN: NK, PI, WT and IT as P. impolita Wahlenb. (Lazkov \& Sultanova 2011); SF* - "Jalal-Abad region, Fergana range, Aksy distr., lake Sary-Chelek env.

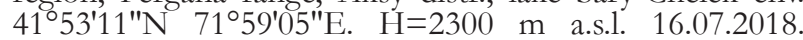
S.A. Usmanov" (ALTB).

General distribution: Europe; North (except the northern part), Southwest, Central (up to northwestern China), East (north), South (northwest) Asia; North America.

\section{Potentilla blanda Soják}

KYRGYZSTAN: WT* - "Western Tian Shan. N slope of Chatkal range, Mazar-su gorge env., subalpine belt. 17.08.1962. No. 191. V. Pavlov" (MW0840081); NK* "Kirgisia, Tian-Schan montes Kirgizskij Chrebet: locis graminosis in valle rivuli Ala-Arca ad meridiem versus ab oppido Frunze, $\mathrm{H}=1500-2000$ m a.s.l. 8.07.1979. J. Soják" (E00664151 et E00664152).

General distribution: Central Asia.

The species was described from the specimens collected in Alai valley: Alai range, near Sary-Tash (Soják 1983). Type specimens of $P$. blanda are stored in LE herbarium. Apart from Sary-Tasha env., we identified new localities of this rare species in A: "right bank of Ailyama riv., alpine meadow" (MW0840431); "Berg-Region bei Irkeschtam" (DR) P. blanda was previously cited for PI: "Tian Shan. TerskeyTau, Korumda valley (later. valley of Konurulen riv.). Alpine meadow and tundra. 1.06.1902. No. 19. V. Sapozhnikov" (TK) (Kechaykin 2016).

\section{Potentilla desertorum Bunge}

KYRGYZSTAN: NK; WT; SF; IT; PI* - "Terskei Alatau range, Akterek riv. valley. 07.1961. I. Shchukin" (MW0840181, MW0840180), "Tian Shan, Terskei Alatau range. Chon-Kyzyl-Su riv. basin, right bank of Kashkator riv. H=2950 m a.s.1. 17.07.1932. Zhiryakov" (MW0840175).

General distribution: North (south Siberia) and Central Asia.

\section{Potentilla grisea Juz.}

KYRGYZSTAN: NK; SF; A*_ "Alai valley, Kuramda mountain, subalpine meadow. 15.08.1953. Tzipinskaya" (TK), "S slope of Alai range, Koksu riv. head. Abramov glacier basin. $\mathrm{H}=3900 \mathrm{~m}$ a.s.l. 13.07.1986. V. Nozdryuhin" (TÅSH).

General distribution: Central Asia
Potentilla hololeuca Boiss. ex Lehm.

KYRGYZSTAN: NK; PI; WT; SF; IT; A* - "Alai range, alpine meadows, Lenin Peak env. 19-21.07.1975. S. Tumanyan" (MW0894818), "S slope of Alai range. Koksu riv. head, Abramov glacier basin. $\mathrm{H}=3850 \mathrm{~m}$ a.s.l. 15.08.1986. V. Nozdryuhin" (TASH).

General distribution: Southwest and Central Asia.

Potentilla inclinata Vill., nom. cons.

KYRGYZSTAN: NK, WT and IT as P. canescens Besser (Lazkov \& Sultanova 2011); SF* - "Jalal-Abad region, Fergana range, Bazar-Koron distr., Kara-Unkur riv. head. $41^{\circ} 22^{\prime} 54^{\prime \prime} \mathrm{N}, 72^{\circ} 56^{\prime} 04^{\prime \prime}$ E. $\mathrm{H}=2200 \mathrm{~m}$ a.s.l. 22.07.2018. S.A. Usmanov" (ALTB), "Jalal-Abad region, Fergana range, Aksy distr., lake Sary Chelek env. 41 ${ }^{\circ} 53^{\prime} 11^{\prime \prime N} 71^{\circ} 59^{\prime} 05^{\prime \prime} \mathrm{E}$. $\mathrm{H}=2300 \mathrm{~m}$ a.s.l. 16.07.2018. S.A. Usmanov" (ALTB), "JalalAbad region, Fergana range, Suzak distr., $5 \mathrm{~km}$ north of vill. Kara-Alma. $41^{\circ} 13^{\prime} 53^{\prime \prime} \mathrm{N} 73^{\circ} 19^{\prime} 54^{\prime \prime E}$. $\mathrm{H}=1500 \mathrm{~m}$ a.s.l. 18.07.2018. S.A. Usmanov" (ALTB).

General distribution: Europe; North (Altai), Southwest and Central (up to northwestern China) Asia; North America.

Studies by European scientists have shown that the type specimens of $P$. inclinata and $P$. canescens are identical (Kurtto et al. 2004, Soják 2005, Gregor et al. 2009). A stabilized hybrid species of $P$. inclinata results from hybridization between $P$. argentea $\mathrm{L}$. and $P$. recta $\mathrm{L}$. Most of the Soviet and Russian botanists consider this taxon as $P$. canescens, a species described much later than $P$. inclinata. The name $P$. inclinata was preserved vs. the previously unknown homotypic synonym P. assurgens Vill. (Gregor et al. 2009).

\section{Potentilla multifida L.}

KYRGYZSTAN: NK, PI, W'T, IT and A as P. asiae-mediae Ovcz. et Koczk. (Lazkov \& Sultanova 2011); SF* - "Turkestan range, Karavshin riv. head, Karasu gorge above vill. Vorukh. $\mathrm{H}=2000-2300 \mathrm{~m}$ a.s.l. 27.07.1989. R.G. Arefieva" (MW0839891 and MW0839892), "Fergana region, Isfayram-Sai, road up to Tengizbai pass, on rocks. 22.06.1931. No. 143. S. Lipschitz" (MW0840394), "Turkestania, prov. Fergana. Distr. Osch. In pratis in valle fl. Gulcza. 22.05.1900. W. Tranzschel" (DR); CT* - "Central Tian Shan, mouth of Berkut riv. valley (tributary of SaryDjaz riv.). 07.1961. I. Shchukin" (MW0840412), "Central Tian Shan, Sary-Djaz riv. basin, Sulun tract, mountain syrty. 16.07.1959. V. Zazhigin" (MW0840414, MW0840413).

General distribution: Europe; North, Southwest (Iran), Central, and South (northwest) Asia.

In one of the studies, Soják considered $P$. asiae-mediae as a synonym for P. multifida (Soják 2004). Our herbarium and field studies showed that these taxa are virtually identical.

\section{Potentilla nervosa Juz.}

KYRGYZSTAN: NK; PI; WT; SF; IT; A* _ "Right bank of Ailyama riv., alpine meadow. 1.07.1986. No. 544-5. V. Kuvaev, G. Skrynnikov" (MW0840431), "Alai valley, vill. Bardoba env., rocky slopes. 13.08.1931. No. 838. S. Lipschitz" (MW0840422), "Alai valley, $\mathrm{N}$ side of Bardoba gorge, alpine lawn. 7.07.1931. No. 410. S. Lipschitz" (MW0840423, MW0840424), "East Alai, between Ailyama riv. and Tau-Murun pass. 7.08.1933. No. 619. I. Tyshchenko" (TASH), "Alai range. S slopes. Road to Irkeshtam outpost, $37 \mathrm{~km}$ from Sary-Tash. H=3200 m a.s.l. 2.08.1962. No. 164. Puchkova" (TASH), "Zaalaisky range. Right bank of Nura riv., $10 \mathrm{~km}$ from Irkeshtam outpost. $\mathrm{H}=2850 \mathrm{~m}$ a.s.l. 4.08.1962. No. 313. Puchkova" (TASH); CT* - "Central Tian Shan, mouth of Berkut riv. valley (tributary of Sary-Djaz riv.). 07.1956. I. Shchukin" (MW0840426).

\section{General distribution: Central Asia.}

\section{Potentilla pamiroalaica Juz.}

KYRGYZSTAN: WT; SF; A* _ "Zaalaisky range, Pamir highway, Bardoba outpost, small tributary of Kyzyl-Art riv., $\mathrm{N}$ slope of the valley. $39^{\circ} 30^{\prime} 29^{\prime \prime} \mathrm{N}, 73^{\circ} 16^{\prime} 40^{\prime \prime}$ E. 28.07.2016. No. A-1812. A. Seregin" (MW0894824), "Osh region, SaryTash env. along Pamir highway. 27.06.1949. No. 1480. 
S.S. Sakhobiddinov, A.D. Li" (TASH), "E part of Alai valley. Foothills of Zaalaisky range, a hill near Kurumda riv., $3 \mathrm{~km}$ to W. 24.08.1929. No. 266, 270. E. Korovin, I. Tyshchenko" (TASH); IT* - "Central Tian Shan. Kochkur riv. basin, vill. Kochkur env. (second terrace of Chu riv.). 3.06.1926. No. 15. A. Polyakova" (TASH), "Przhevalsky distr., near Petrov glacier. $\mathrm{H}=3600 \mathrm{~m}$ a.s.l. 1935 year. [P.]D. [G]imer" (MW0840519).

General distribution: North (Altai) and Central Asia.

\section{Potentilla pensylvanica L.}

KYRGYZSTAN: NK, PI and WT as P. strigosa Pall. ex Tratt. (Lazkov \& Sultanova 2014); IT* - "Central Tian Shan. Eastern part of Susamyr valley, Jamansai tract. 21.07.1965. No. 206. A. Pyataeva, R. Kolomazova" (TASH).

General distribution: Southern and Eastern Europe; North, Central and East (north) Asia; North and Central America.

Potentilla tephroleuca Th. Wolf

KYRGYZSTAN: WT; IT* - "Ketmen-Tyube depression, Iyru-suu riv., alpine zone. 18.07.1961. No. 1110. M. Botbaeva" (MW0840702).

General distribution: Central Asia.

Potentilla virgata Lehm.

KYRGYZSTAN: NK; PI; WT; IT; A* - "Vill. Irkeshtam env. 18.09.1940" (MW0840780).

General distribution: Eastern Europe; North (southern Siberia) and Central Asia.

\section{Sibbaldia cuneata Edgew.}

KYRGYZSTAN: NK as S. olgae Juz. et Ovcz. (Lazkov \& Sultanova 2011); WT* (on the border with IT) - "KetmenTyube depression, Talas Ala-Too, Muztor pass, moraine. 14.07.1960. No. 2423. M. Botbaeva" (MW0840793).

General distribution: Central, South and East Asia.

\section{Other additions}

1. In 1986, Soják described a new species of Potentilla exuta Soják based on materials collected earlier in Mongolia, Eastern Siberia and Kyrgyzstan (Soják 1986). Subsequently, no data on $P$. exuta were available in the studies on the flora of Kyrgyzstan. Type specimens of this species were collected from Kuyandy riv. head, Przhevalsky distr. by Sapozhnikov in 1913. This locality in Sary-Djaz riv. basin is a part of the Central Tian Shan (CT) (Fig. 1). The specimen from Kuyandy riv. stored in LE collection is a paratype of P. exuta.

2. According to Lazkov \& Sultanova (2011), Potentilla ferganensis Soják can be found in the Prifergansky distr. of Kyrgyzstan (SF). This species is described from specimens collected in Suyek tract, At-Bashinsky distr., which corresponds to the Inner Tian Shan (IT) (Fig. 1). The only type specimen of P. ferganensis is stored in LE herbarium.

3. In 1987, Potentilla penniphylla (Soják 1987b) was described from the southwestern and northeastern parts of Kyrgyzstan, but the species was not included in the lists of species growing in the study area. According to the protolog and type materials stored in LE, P. penniphylla Soják occurs in the following biogeographic regions of Kyrgyzstan: SF - Alai range: Cholak boguz (locus classicus); CT - Kuelu riv. valley, right tributary of Sary-Djaz riv.; SF - Alai range, Osh distr., Tor-Chetan (Fig. 1). Note that we did not find the herbarium specimen from TorChetan. Recently P. penniphylla has been newly recorded for the flora of Russia: the south-east of Western Siberia (Kechaykin 2016). Thus, new localities of P. penniphylla are likely to be found in the areas between Kyrgyzstan and Western Siberia.
4. According to Lazkov \& Sultanova (2014), Potentilla tobolensis Th. Wolf ex Juz. is distributed in PI and WT biogeographic regions of Kyrgyzstan. In addition, a new locality was reported for P. tobolensis: Toguz-Torau tract, Kokirim riv., vill. Titovka env. (Kechaykin 2016). This collection stored in TK herbarium belongs to the Inner Tian Shan (IT). P. tobolensis, hybridogenic taxon with a wide range of habitat, is actively distributed by seeds dispersed along the roads, railway tracks, and along the banks of large rivers, lakes and water reservoirs (Kechaykin 2012, 2013).

\section{Analysis of endemism of the genus Potentilla L. S. str. flora of Kyrgyzstan}

Endemic elements are a specific part of any flora. Identification of these elements and their subsequent research are crucial for differentiation of particular flora from others. In some cases, endemic species grown in isolation in small localities are carriers of a unique genebank, and therefore are of high conservation priority (Lazkov \& Umralina 2015). According to the Cadastre of Flora of Kyrgyzstan (Lazkov \& Sultanova 2014), 15 endemic and subendemic species of the genus Potentilla s. str. can be found in Kyrgyzstan, some of them are quite rare and localized within specific boundaries. However, the atlas Endemics and Rare Plant Species of Kyrgyzstan does not provide any data on these species (Lazkov \& Umralina 2015). Thus, the analysis of endemism of the genus Potentilla from Kyrgyzstan is of high relevance.

A list of endemic and subendemic species proposed by Lazkov \& Sultanova (2014) with indication of species distribution in Kyrgyzstan with regard to new data is provided below

Legends:

$[\mathbf{E}]$ - endemic species (occur in Kyrgyzstan only);

[SE] - sub-endemic species (cover Kyrgyzstan and some areas of Central Asian republics of the former USSR and Northwest China).

1. P. $\times$ ala-arczae Soják: NK; $[\mathbf{E}]$.

2. \#P. algida Soják: NK, SF; [SE].

3. \#P. asiae-mediae Ovcz. et Koczk.: NK, PI, SF, WT, IT, A, CT; [SE].

4. \#P. asiatica (Th.Wolf) Juz.: NK, PI, W'T, SF; [SE].

5. P. $\times$ bishkekeensis Soják: NK; [E].

6. P. fedtschenkoana Siegfr. ex Th.Wolf: WT, SF; [SE].

7. P. ferganensis Soják: IT; [E].

8. \#P. grisea Juz.: A, NK, SF; [SE]

9. P. kamelinii Lazkov: W'T; [E].

10. P. nervosa Juz.: A, NK, PI, W', SF, IT, CT; [SE].

11. \#P. pamirica Th.Wolf: SF; [SE].

12. \#P. pamiroalaica Juz.: A, IT, W'T, SF; [SE].

13. \#P. stanjukoviczii Ovcz. et Koczk.: A, IT, PI, CT; [SE].

14. P. tephrolenca ('Th. Wolf) B. Fedtsch.: IT, WT; [SE].

15. P. tephrosericea Juz.: W'T, SF; [SE].

We propose to exclude some of the Potentilla species listed above, which, according to some data, have a wider area of distribution (marked with "\#" in the list) from the category of subendemic species of Kyrgyzstan. These species include P. algida growing in Afghanistan (Soják 2012); P. asiaemediae that is considered synonymous with $P$. multifida (see above); $P$. asiatica growing in the area from Afghanistan to Eastern Siberia (Soják 2004, 2012, Kechaykin 2012); P. grisea restricted to Afghanistan, Pakistan and Kashmir (Soják 2009, 2012); P. pamirica and P. pamiroalaica distributed from Turkey to Altai (Soják 2007, 2012, Kurbatsky \& Ebel 2011, 
Kechaykin et al. 2014); P. stanjukoviczii that is considered synonymous with $P$. agrimonioides (see above).

Thus, only 8 Potentilla endemics occur in the flora of Kyrgyzstan, of which 4 species are local endemics that require special observation and monitoring $(P . \times$ ala-arczae $), P . \times$ bishkekensis, $P$. ferganensis and P. kamelinii (Fig. 1), and 4 species are subendemic (P. fedtschenkoana, P. nervosa, P. tephroleuca and $P$. tephrosericea). The number of endemics and subendemics is $18.6 \%$ of the total number of Potentilla s. str. growing in Kyrgyzstan. Such low percentage, in our opinion, does not reflect the autochthonous tendencies in the formation of the Potentilla species composition in this area. The highest occurrence of endemics and subendemics of Potentilla in the flora of Kyrgyzstan is observed in the Western Tian Shan biogeographic region, where 5 species are found to grow. In addition, three more Potentilla species found nowhere else and associated with $P$. fedtschenkoana have been described from the Western Tian Shan. In Uzbekistan, these are $P . \times$ solitaria Soják and P. tschimganica Soják found in the Big Chimgan Mountain Range; in Kazakhstan - P. karatavica Juz. growing in the Karatau range. These species are likely to occur in Kyrgyzstan as they grow in close proximity to the border. The physiographic conditions of the Western Tian Shan make it an area with active speciation in the genus Potentilla associated primarily with processes of hybridization.

\section{CONCLUSION}

Within five years after the release of the second volume of the Cadastre of Flora of Kyrgyzstan, the number of species of the genus Potentilla in the study area have increased by nine taxa, and now it accounts for 49 species s. 1. or 43 species s. str. In this paper, 5 new Potentilla species with specific localities have been newly recorded for the first time for the flora of Kyrgyzstan. Of these, P. tuvinica is a newly recorded species from the Tian Shan mountain range. The conducted analysis of endemism showed that 8 endemic and subendemic Potentilla species occur in the flora of Kyrgyzstan. The endemics and subendemics of Potentilla are mostly found in the Western Tian Shan biogeographic region associated with species formation of the genus in this area. We believe that the study of the genus Potentilla and close taxa is currently being initiated in Kyrgyzstan, and in the Tian Shan and Pamir-Alai mountain ranges. New findings are expected to expand the overall picture of the genus Potentilla in Central Asia. In conclusion, we would like to quote the words of R.V. Kamelin, a famous expert on the flora of Central Asia, "Such is the flora of Kyrgyzstan, which has not been fully studied in terms of its systematic composition and for practical needs" (Kamelin 2002).

\section{ACKNOWLEDGEMENTS}

We are grateful to the Directors/Curators of the following herbaria for herbarium and library facilities: DR, LE, MW, PR, TASH and TK. This article was prepared with the support of state assignment (No. FZMW-2020-003).

\section{LITERATURE CITED}

Abdrashitova, N.I., H. Aspok, U. Aspok, E.A. Bardzimashvili, N.V. Gabrid, V.A. Gorbatyuk, O.G. Gorbunov et al. 1996. Superclass Hexapoda (Entognatha and Insecta).
In: Cadastre of the genetic fund of Kyrgysstan, vol. 3. Ecological movement of Kyrgyzstan "Aleine" Press, Bishkek, 400 pp. (in Russian) [Абрашитова Н.И., Аспок Х., Аспок У., Бардзимашвили Е.А., ГабриА Н.В., Гобратюк В.А., Горбунов О.Г. и Ар. 1996. НаАкласс Нехарода - шестиногие (Entognatha and Insecta) // КаАастр генетического фонда Кыргазстана. Т. 3 / Бишкек: экомогическое Авижение Кыргызстана "А^ейне". 400 с.].

Adylov, T.A. 1976. Potentilla L. In: Key to plants of the Middle Asia, vol. 5, (M.G. Pachomova, ed.), pp. 171-191, Izd-vo "Fan" Uzbekskoi SSR, Tashkent (in Russian). [Адылов T.A. 1976. Род Potentilla L. - Аапчатка / / Определитель растений Средней Азии. Т. 5 / поА. реА. М.Г. Пахомовой. Ташкент: изА-во "Фан" Узбекской ССР. С. 171-191]

Artemov, I.A. 2005. New species of Potentilla L. from Western Tuva. Turczaninowia 8(1):5-10 (in Russian with English summary). [Артемов И.А. 2005. Новый виА Potentilla L. из ЗапаАной Тувы / / Turczaninowia. T. 8, № 1. С. 5-10].

Baytenov, M.B. 1961. Potentilla L. In: Flora of Kazakhstan, vol. 4, (N.V. Pavlov, ed.), pp. 420-448, Izd-vo Akademii Nauk Kazahskoi SSR, Almaty (in Russian). [Байтенов М.Б.

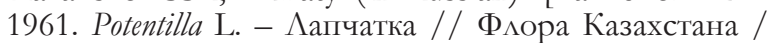
под реА. акаА. Н.В. Павцова. Алма-Ата: изА-во АН Казахской ССР. Т. 4. С. 420-448].

Blinovsky, K.V. 1950. Potentilla L. In: Flora of Turkmenistan, vol. 4, (B.K. Shishkin, ed.), pp. 50-56, Izd-vo Nauka, Ashgabad (in Russian). [БАиновский К.B. 1950. Род Potentilla L. Аапчатка // ФАора Туркмении. / под реА. Б.К. Шишкина. Ашхабад: изд-во Наука. Т. 4. С. 50-56].

Botchantsev, V.P. 1955. Potentilla L. In: Flora of Uzbekistan, vol. 3, (A.I. Vvedenskii, ed.), pp. 305-329, Izd-vo Akademii Nauk Uzbekskoi SSR, Tashkent (in Russian). (Бочанцев В.П. 1955. Род Potentilla L. - Мапчатка // ФАора Узбекистана / под. реА. А.И. ВвеАенского. Ташкент: изА-во АН УзССР. Т. 3. С. 305-329].

Braun, U. \& B. Heuchert 2013. D.F.K. von Schlechtendal's examination of Potentilla species in CL von Willdenow's herbarium published in 1816 - a nomenclatural correction. Schlechtendalia 27:1-4.

Gregor, T., V. Poncet \& J.-M. Tison 2009. (1891) Proposal to conserve the name Potentilla inclinata against $P$. assurgens (Rosaceae). Taxon 58(2):651-652.

Gundegmaa, V. \& A. Kechaykin 2018. A new intersectional hybrid in the genus Potentilla (Rosaceae) from Northern Mongolia. Turczaninowia 21(1):174-179.

Juzepchuk, S.V. 1941. Rosoideae. In: Flora of the USSR, vol. 10, (V.L. Komarov, ed.), pp. 1-508, Izd-vo Akademii Nauk SSSR, Moscow \& Leningrad (in Russian). [Юзепчук С.В. 1941. Rosoideae // ФАора СССР / поА реА.

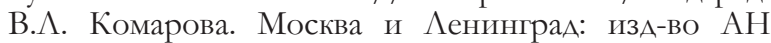
CCCP. T. 10. C. 1-508].

Kamelin, R.V. 2002. Introduction. A brief overview of the vegetation of Kyrgyzstan. In: Umbelliferae of Kyrgyzstan, (M.G. Pimenov \& E.V. Kljuykov, eds.), pp. 3-18, KMK Scientific Press Ltd., Moscow (in Russian). [Камелин P.B. 2002. Введение. Краткий обзор растительности Киргизии // Зонтичные (Umbelliferae) Киргизии / поА. ред. М.Г. Пименова, Е.В. КАюйкова. Москва: КМК Scientific Press Ltd. C. 3-18].

Kashchenko, L.I. 1957. Potentilla L. In: Flora of the Kirghiz SSR: Key to plants of the Kirghiz SSR, vol. 7, (A.I. Vvedenskii, ed.), pp. 70-84. Izd-vo Akademii Nauk Kirgizskoi SSR, Frunze (in Russian). [Кащенко А.И. 1957. РоА Potentilla L. - Аапчатка // ФАора Киргизской ССР: ОпреАелитель растений Киргизской ССР. / под реА. А.И. Вве- 
Аенского. Фрунзе: ИзА-во АН Киргизской ССР. Т. 7. C. 70-84].

Kechaykin, A.A. 2012. New findings of Potentilla L. (Rosaceae) in South-West Siberia and East Kazakhstan. Turczaninowia 15(1):55-57 (in Russian with English abstract). [Кечайкин А.А. 2012. Новые находки видов Potentilla L. (Rosaceae) в Юго-Западной Сибири и Восточном Казахстане // Turczaninowia. T. 15, № 1. C. 55-57].

Kechaykin, A.A. 2016. Floristic findings of the genus Potentilla L. (Rosaceae) on materials of the Herbarium of P.N. Krylov (TK). Acta Biologica Sibirica 2(1):7-20 (in Russian with English abstract). [Кечайкин А.А. 2016. Фмористические находки из рода Potentilla L. (Rosaceae) по материалам гербария им. П.Н. Крылова (ТК) // Acta Biologica Sibirica. T. 2, № 1. C. 7-20].

Kechaykin, A.A. \& A.I Shmakov. 2016. A system of subtribe Potentillinae J. Presl (Rosaceae Juss.). Turczaninowia 19(4):114-128.

Kechaykin, A.A., S.V. Smirnov, A.I. Shmakov, R.V. Kamelin, A.V. Vaganov \& A.V. Galkin 2013. Floristic findings in the south of West Siberia and Kazakhstan. Turczaninowia 16(4):19-22 (in Russian with English abstract). [Кечайкин А.А., Смирнов С.В., Шмаков А.И., Камелин Р.В., Ваганов А.В., Галькин А.В. 2013. ФАористические находки на юго Западной Сибири и в Казахстане // Turczaninowia. T. 16, № 4. С. 19-22].

Kechaykin, A.A., A.I. Shmakov, H. Hurka, B. Neuffer, B. Oyuntsetseg, D. Darihand \& N. Friesen 2014. New findings in the flora of Mongolia. Part 1. Turczaninowia 17(1):57-65.

Kurbatsky, V.I. \& A.I. Ebel 2011. Potentilla pamiroalaica Juz. - rare species for flora of Russia. Sistematicheskie Zametki po Materialam Gerbarii Imeni P.N. Krylova pri Tomskom Gosudarstvennom Universitete 104:34-35 (in Russian with English abstract). [Курбатский В.И., Эбемь А.А. 2011. Potentilla pamiroalaica Juz. - редкий виА Аля фморы России // Сист. зам. по матер. Гербария им. П.Н. Крылова. Вып. 104. C. 34-35].

Kurtto, A., R. Lampinen \& L. Junikka 2004. Rosaceae (Spiraea to Fragaria, excl. Rubus). In: Atlas Florae Europaeae. Distribution of Vascular Plants in Europe, vol. 13, pp. 1-320. The Committee for Mapping the Flora of Europe \& Societas Biologica Fennica Vanamo, Helsinki.

Lazkov, G.A. \& B.A. Sultanova 2011. Checklist of vascular plants of Kyrgyzstan. Norrlinia 24:1-166 (in Russian with English abstract). [Аазьков Г.А., Султанова Б.А. 2011. Кадастр флоры Кыргызстана: сосудистые растения // Norrlinia. T. 16. C. 1-166].

Lazkov, G.A. \& B.A. Sultanova 2014. Checklist of vascular plants of Kyrgyzstan. Izd-vo Natsional'noi Akademii Nauk Kirgizskoi Respubliki, Bishkek, 126 pp. (in Russian). [Аазьков Г.А., Султанова Б.А. 2014. Кадастр флоры Кыргызстана. Сосудистые растения. Бишкек: изА-во НАК Кыргызской Республики. 126 с.].

Lazkov, G.A. \& A.R. Umralina 2015. Endemic and rare plant species of Kyrgyzstan (Atlas). The second edition revised and updated. Izd-vo Ankara, Bishkek, 237 pp. (in Russian with English abstract). [Аазьков Г.А., Умралина А.Р. 2015. Эндемики и редкие и виды растений Кыргызстана (Атлас). Издание второе, доработанное и Аополненное. Бишкек: изА-во Анкара. 237 с.].

Li, C-L., H. Ikeda \& H. Ohba 2003. Potentilla, Comarum, Sibbaldia, Chamaerhodos, Fragaria, and Duchesnea. In: Flora of China, vol. 9, (Z. Wu \& P. Reven, eds.), pp. 291-339, Missouri Botanical Garden Press, St. Louis.

Lipsky, W.I. 1910. Materials for the flora of Middle Asia III. Monographic Review of Middle Asian Potentilla. Acta
Horti Petropolitani 26:290-405 (in Russian). [Аипский В.И. 1910. Материалы Аля фморы Средней Азии // Труды Императорского С.-Петербургского ботанического сада. Вып. 26. С. 290-405].

Ovczinnikov, P.N. \& T.F. Koczkareva 1975. Potentilla L. In: Flora of the Tadjik SSR, vol. 4, (P.N. Ovczinnikov, ed.), pp. 388-427, Izd-vo Nauka, Leningrad (in Russian). [Овчинников П.Н., Кочкарева Т.Ф. 1975. Род Potentilla L. - Аапчатка // ФАора Таджикской ССР / поА. ред. П.Н. Овчинникова. Аенинград: изА-во Наука. С. 388-427].

Royal Botanic Garden Edinburgh 2019. Royal Botanic Garden Edinburgh Herbarium (E). Available from: https://doi. org/10.15468/ypoair. Last accessed 15.01.2019.

Royal Botanic Gardens Kew 2019. Royal Botanic Gardens, Kew - Herbarium Specimens. Available from: https://doi. org/10.15468/ly60bx. Last accessed 15.01.2019.

Schlechtendal, D.F.K. 1816. Uebersicht der in Willdenow's Pflanzensammlung aufbewahrten Potentillen. Magazin für die neuesten Entdeckungen in der gesammten Naturkunde, Gesellschaft Naturforschender Freunde zu Berlin 7:283-297.

Seregin, A.P. 2019. Moscow University Herbarium (MW). Version 1.65. Lomonosov Moscow State University. Available from: https://doi.org/10.15468/cpnhcc. Last accessed 15.01.2019.

Shan, M. 2009. Potentilla L. In: Flora of Pakistan, vol. 216, (S.I. Ali \& M. Qaiser, eds.), pp. 14-91, Institute of Plant Conservation, University of Karachi, Karachi \& Missouri Botanical Garden Press, St. Louis.

Soják, J. 1983. Potentilla blanda Soják sp. n. (ex Asia Media; sect. Niveae). Casopis Národníbo Muzea v Praze, Rada Prírodovédna 151(4):206.

Soják, J. 1986. Notes on Potentilla (Rosaceae). II. Some new species from Mongolia. Willdenowia 16:125-142.

Soják, J. 1987a. Notes on Potentilla V. Potentilla pensylvanica in the Old World. Preslia 59(4):289-305.

Soják, J. 1987b. Notes on Potentilla (Rosaceae). III. Some new taxa from Asia. Botanische Jahrbücher für Systematik, Pflanzengeschichte und Pflanzengeographie 109(1):25-48.

Soják, J. 1988. Notes on Potentilla (Rosaceae). VII. Some Himalayan taxa. Candollea 43:437-453.

Soják, J. 2004. Potentilla L. (Rosaceae) and related genera in the former USSR (identification key, checklist and figures). Notes on Potentilla XVI. Botanische Jahrbücher für Systematik, Pflanzengeschichte und Pflanzengeographie 125(3):253-340.

Soják, J. 2005. Potentilla L. s. 1. (Rosaceae) in Flora Europae Orientalis (Notes on Potentilla XVIII). Candollea 60(1):59-78.

Soják, J. 2007. Potentilla (Rosaceae) in China. Notes on Potentilla XIX. Harvard Papers in Botany 12:285-324.

Soják, J. 2009. Potentilla L. (Rosaceae) in the former USSR; second part: comments Notes on Potentilla XXIV. Feddes Repertorium 120:185-217.

Soják, J. 2012. Potentilla L. (Rosaceae) and related genera in Asia (excluding the former USSR), Africa and New Guinea. Notes on Potentilla XXVIII. Plant Diversity and Evolution 130:7-157.

The International Plant Name Index. 2019. Available from: http://www.ipni.org/. Last accessed 25.01.2019.

Thiers, B.M. 2019. Index Herbariorum: A global directory of public herbaria and associated staff. New York Botanical Garden's Virtual Herbarium. New York Botanical Garden, Bronx, New York, USA. Available from: http://sweetgum.nybg. org/science/ih/. Last accessed 22.01.2019.

Tropicos.org. Missouri Botanical Garden. 2019. Available from: http:/ / www.tropicos.org/. Last accessed 25.01.2019. 
Turland, N.J., J.H. Wiersema, F.R. Barrie, W. Greuter, D.L. Hawksworth, P.S. Herendeen, S. Knapp et al. 2018. International Code of Nomenclature for algae, fungi, and plants (Shenzhen Code) adopted by the Nineteenth International Botanical Congress Shenzhen, China, July 2017. Regnum Vegetabile 159. Koeltz Botanical Books, Glashütten. https://doi.org/10.12705/Code.2018
Urgamal, M., B. Oyuntsetseg, D. Nyambayar, Ch. Dulamsuren 2014. Conspectus of the vascular plants of Mongolia. Admon Printing Press, Ulaanbaatar, 334 pp. 